\title{
Project-based learning to improve scientific literacy for primary education postgraduate students in science subject
}

\author{
Endang Widi Winarni ${ }^{1 *}$, Endina Putri Purwandari ${ }^{2}$ \\ ${ }^{1}$ Department of Primary Education, Graduate School, Universitas Bengkulu \\ ${ }^{2}$ Department Information System, Engineering Faculty, Universitas Bengkulu \\ Jalan W.R Supratman, Kandang Limun, Bengkulu, 38371, Indonesia \\ *Corresponding Author. E-mail: endangwidi@unib.ac.id
}

Received: 11 March 2020; Revised: 17 May 2020; Accepted: 18 June 2020

\begin{abstract}
The research aimed to describe the learning activities and the ability of scientific literacy (attitude, context, knowledge, and competence) Students of Primary Education Postgraduate Program of Bengkulu University in natural science subjects by using the PjBL model. The Classroom Action Research done in three cycles for Primary Education Postgraduate Program students of Bengkulu University in the first semester of 2019/2020 academic year. Instrument and data collection techniques are observations, tests, and rubrics. The observation was on student activities in learning and aspects of caring for the environment and caring for health. The instruments were HOTS test and rubric. The science aspect uses the student report assessment sheet. The indicators of successful actions were the activities of lecturers and students in teaching and learning by using PjBL in good categories, and the percentage of students who show attitudes, context, knowledge, and competencies of science meet good categories at least $80 \%$. The results of this research are the using of Project-Based Learning model can improve the learning activities of Primary Education Postgraduate Program Students of Bengkulu University in a natural science subject and can improve the scientific literacy aspects of an attitude, context, knowledge, and competencies for Primary Education Postgraduate Program in the science subject.
\end{abstract}

Keywords: Project-Based Learning, Scientific Literacy, Natural Science Subject

How to Cite: Winarni, E. W., \& Purwandari, E. P. (2020). Project-based learning to improve scientific literacy for primary education postgraduate students in science subject. Jurnal Prima Edukasia, 8(1), 67-77. doi:https://doi.org/10.21831/jpe.v8i1.30618

\section{Introduction}

Mastery of science and technology in the 21st century is the main successful key for the nation. Science education plays an important role in producing and shaping students who can think critically, logically, creatively, innovatively, with local, national, and international competitiveness (Winarni \& Purwandari, 2019). Therefore, science education becomes the main foundation of education for students in knowing and implementing science in daily life or developing scientific literacy.

Science education was originally designed in schools to prepare and provide a basic understanding of students (Fitzgerald \& Smith, 2016). The nature of science is the process of activities carried out by scientists to gain knowledge and attitudes in science activities(Winarni, 2018a). Science has four components, namely: scientific processes such as observing, classifying, predicting, designing and experimenting; scientific products, such as principles, concepts, laws, theories; scientific attitudes such as objective, careful and honest; and application, practicing the scientific methods and science concepts in daily life. The UNESCO Education conference in 1990, science learning in schools has a broader aim to equipping students with scientific literacy. PISA 2015 defines scientific literacy as abilities in context, knowledge, attitudes, and competencies (Organisation for Economic Co-operation and Development, 2016).

One of the literacy dimensions is environmental literacy. There are seven components for environmental literacy, namely environmental issues, the earth system interactions, material cycles and energy flow, populations, communities and ecosystems, human and natural resources, environment and health, environment, and society (Winarni \& Purwandari, 2019). Environmental literacy is the focus 
research, namely population, society, and ecosystems as well as environment and health. Environmental care can be understood by students as a human response through actions to prevent environmental damage and its effect on health. Student responses classified into three, namely cognitive, affective, and conative. Cognitive responses are perception responses and statements. The affective response is a response to an action statement. The conative response is a response in action or behavior.

The student's ability of scientific literacy in Indonesia is very low and far below the international standard scores set by the Organization for Economic Co-operation and Development (OECD). Based on the results of OECD, Indonesia's PISA ranking in 2009 was 57 out of 67 countries with a score of 383, in 2012 Indonesia ranked 64 out of 65 countries with a score of 382 (Organization for Economic Co-operation and Development, 2019). Furthermore, in 2015 Indonesia was ranked 64 out of 72 participating countries, with a score of 403 . The low scientific literacy of these students was due to the science learning process which had not provided opportunities for students to develop critical thinking skills.

The central elements for science education reform in schools are the science curriculum that centered on the inquiry or discovery process, professional development, material stabilization, and a comprehensive and authentic assessment system. Learning science directed at real-world problems as a context for students to learn and to solve problems critically. For this reason, teachers must choose approaches, models, and learning methods that can facilitate the achievement of science learning objectives.

The project learning model emphasizes student activities in a project to solve community and environmental problems (Sari, 2018). The learning-focused in the concepts and principles of a discipline of study, involving learners in problem-solving investigations and allowing students to construct their knowledge, and producing tangible products as an innovation in science. The novelty of this research is the scientific literacy instrument and assessment for attitude, context, knowledge, and competence aspects. The PjBL learning model is very good in developing decision-making skills, creative abilities, and problem-solving abilities (Cook et al., 2012; Kusumaningrum \& Djukri, 2016).

The problem of this research is how the learning activities and the scientific literacy ability in attitudes, context, knowledge, and competencies for the primary education postgraduate students at the University of Bengkulu that using the PjBL model in the science lectures. The study's purpose is to describe the learning activities and the scientific literacy ability in attitude, context, knowledge, and competence for the primary education postgraduate students at the University of Bengkulu that using the PjBL model in the science lectures.

\section{Method}

This research used the Classroom Action Research (CAR) carried out in three cycles. Each CAR consists of planning, implementing, observing, and reflecting (Winarni, 2018b). The first cycle starts from identification as a reflection, the researcher conducts discussion with the lecturers. Then, analyze the student's worksheet and the lecture material scope.

This research conducted at the primary education postgraduate students at the University of Bengkulu during the first semester of 2019/2020. The Cycle I research conducted on Saturday, October 12th, 2019 for growth and development topics. Cycle II conducted on Saturday, October 19th, 2019 for topics about the abiotic and biotic ecosystem interaction. The Cycle III conducted on Saturday, October 26th, 2019 for the metabolic and human body, the digestive system, and the circulatory system. The data sources are 40 students that taking part in the primary education postgraduate students in the first semester with 20 students from class A and 20 students from class B.

The PjBL operational steps are as follows: First, Start with the essential question. Learning begins with essential questions that can assign students assignments in carrying out an activity. Choose a topic that matches the real-world reality and begin with an in-depth investigation. Second, Design a plan for the project. Project planning was done collaboratively between lecturers and students so that they feel to own the project. Third, Create a schedule, include creating a timeline for the project completion, creating the deadline, bringing a new way plan, guiding to create a way that is not related to the project, and asking students to make an explanation about the selection method. Fourth, Monitor the students and the progress of the project. Monitoring was done by facilitating students in each process. A rubric created to simplify the monitoring process that can record all important activities. Fifth, Assessing the 
Jurnal Prima Edukasia, 8 (1), 2020 - 69

Endang Widi Winarni, Endina Putri Purwandari

outcome. The assessment is carried out to assist the lecturer to measure the achievement standards, play a role in evaluating the progress of each student, provide feedback about the student's understanding level, assist the lecturer in developing the next learning strategy. Sixth, Evaluate the experience. The reflection process is carried out individually and in groups. Lecturers and students develop discussions to improve performance during the learning process. Then, the new findings are found to answer the problems raised in the first stage of learning.

There are three instruments used in this research, namely (1) observation sheet consists of the student and lecturer observation activities using Project Based Learning (PjBL) and the science attitude observation about environmental care and health care; (2) students test sheets made and conducted by lecturers following the course description and guidelines in Science subject, especially the contents of Biology and Chemistry; and (3) rubric for project appraisal. The science competency aspect uses a project appraisal in PowerPoint slide with the rubric to measure information completeness, clarity, content correctness, and attractiveness. The science aspects use student report grading sheets with the rubrics of theoretical and applications that linking with daily life.

Data collection techniques for observations, tests, and project appraisal rubrics used observation, HOTS test that conducted at the end of each cycle, and assessment. The instrument consulted with an expert for judgment and validation. The results of expert judgment showed that the instrument was valid for the research field study. Observations made during the learning process, include the student activities observation that focused on the 6 steps of PjBL model, and the evaluation of scientific attitudes especially for the environmental care and health care. The project assessment in the making of PowerPoint media to assess the scientific competencies. The complete information rubric, clarity, correctness of contents, and attractiveness. The context aspect uses the student report assessment with the theoretical and application rubric in daily life.

Data analysis techniques for each variable examined with observation data that analyzed from the lecturer and student activities, science attitudes assessment, test data, and project appraisal data. The observations of lecturer and student activities focused on the 6 steps of the PjBL model with a scale of 1-4 as an indicator that observed in each cycle. The observations for science attitudes assessment were collected during the learning process by giving a score of 1-4. Test data analyzed using an assessment for each Basic Competency in Natural Sciences subject that measured by HOTS. The students' scientific knowledge assessment used a posttest in each cycle with different questions. Test data were analyzed for science competency using a project assessment sheet. The successful indicators were the lecturers and students activity in conducting $\mathrm{PjBL}$ reaches good categories, the student's percentage who showed attitudes reached at least $80 \%$; and the completeness percentage for context, knowledge and science competencies for individually was 75 and classically reached a minimum of $85 \%$.

\section{Result and Discussion}

Result

\section{Learning Activities}

The PjBL learning activities observed include determining of fundamental questions to determine the relevant topics and conduct in-depth investigations, designing project planning, followed by designing the project in groups and working on Student Activity Sheets, arranging the schedule from timelines and deadlines for completing projects, monitoring the progress project observed from activities during project completion, testing results, observed from evaluating project progress and feedback, evaluating experience, observed from reflections on project activities and results. The learning activity observation sheet consists of 10 observation aspects lectures with PjBL. The observations result carried out in the first, second, and third cycles from the PjBL model presented in Table 1.

Based on the first cycle, there are six learning activities in enough category that need improvement, the stage namely determining the fundamental questions, students look less active to conduct investigations following the topic, designing project planning, students still look relaxed when discussing designing project planning, arranging schedules, students orderly conduct experiments and work on the student's worksheet to create timelines and deadlines the project's completion, monitoring students and project progress, students and groups in an orderly manner write down the results of discussions; and evaluating the test results, some students confused in the project to be made and some 
Jurnal Prima Edukasia, 8 (1), 2020 - 70

Endang Widi Winarni, Endina Putri Purwandari

students are enthusiastic when the lecturer provides feedback in learning material as a reinforcement of learning material. The learning activities in the second cycle there are three learning activities in the Enough category that need improvement, the stage namely determining the fundamental questions, students look still less active in conducting investigations by the topic, arranging schedules, students orderly conduct experiments and work on the student's worksheet, and evaluating the test results, some students are enthusiastic when lecturers provide feedback in learning material as a reinforcement of subject matter.

Table 1. Learning Activities

\begin{tabular}{|c|c|c|c|c|c|}
\hline \multirow{4}{*}{$\frac{\text { No. }}{1 .}$} & PjBL Steps & Lecturer Activity & Student Activity & Cycle 1 Cycle 2 & Cycle 3 \\
\hline & \multicolumn{5}{|c|}{ Determination of Basic Questions } \\
\hline & $\begin{array}{l}\text { Ask questions to } \\
\text { determine the } \\
\text { fundamental } \\
\text { questions }\end{array}$ & $\begin{array}{l}\text { The lecturer stimulates } \\
\text { students with essential } \\
\text { questions. }\end{array}$ & $\begin{array}{l}\text { Students respond positively } \\
\text { by answering lecturer } \\
\text { questions. }\end{array}$ & Good & Good \\
\hline & $\begin{array}{l}\text { Determine the } \\
\text { relevant topics and } \\
\text { conduct an in-depth } \\
\text { investigation }\end{array}$ & $\begin{array}{l}\text { Lecturers facilitate } \\
\text { students to conduct in- } \\
\text { depth investigations. }\end{array}$ & $\begin{array}{l}\text { Some students are less } \\
\text { active in conducting } \\
\text { investigations according to } \\
\text { the topic }\end{array}$ & Enough Enough & Good \\
\hline \multicolumn{6}{|c|}{ 2. Design Project Planning } \\
\hline & $\begin{array}{l}\text { Make a group } \\
\text { design }\end{array}$ & $\begin{array}{l}\text { Lecturers guide students } \\
\text { to design projects in } \\
\text { groups of } 6-7 \text { members. }\end{array}$ & $\begin{array}{l}\text { Students create project } \\
\text { designs in groups of 6-7 } \\
\text { members but still look } \\
\text { relaxed. }\end{array}$ & Enough Good & Excellent \\
\hline & $\begin{array}{l}\text { Working on MFIs } \\
\text { for plant growth and } \\
\text { development }\end{array}$ & $\begin{array}{l}\text { Lecturers provide } \\
\text { learning logistics (tools } \\
\text { and materials used) to } \\
\text { work on MFIs. }\end{array}$ & $\begin{array}{l}\text { Students receive learning } \\
\text { logistics (tools and } \\
\text { materials used) to do LKM. }\end{array}$ & Good & Good \\
\hline \multirow[t]{3}{*}{3.} & Arrange Schedule & & & & \\
\hline & $\begin{array}{l}\text { Create a timeline } \\
\text { and deadline for } \\
\text { completing the } \\
\text { project }\end{array}$ & $\begin{array}{l}\text { Lecturers guide students } \\
\text { to create timelines and } \\
\text { deadlines to complete } \\
\text { projects }\end{array}$ & $\begin{array}{l}\text { Some students in an orderly } \\
\text { manner working on LKM } \\
\text { made timelines and } \\
\text { deadlines to complete } \\
\text { projects }\end{array}$ & Enough Enough & Good \\
\hline & $\begin{array}{l}\text { Make an explanation } \\
\text { of the choice of a } \\
\text { way in project } \\
\text { completion }\end{array}$ & $\begin{array}{l}\text { The lecturer guides } \\
\text { students in choosing a } \\
\text { way to complete the } \\
\text { project }\end{array}$ & $\begin{array}{l}\text { Students enthusiastically } \\
\text { discuss a way to complete a } \\
\text { project }\end{array}$ & Good & Excellent \\
\hline \multicolumn{6}{|c|}{ 4. Monitor students and project progress } \\
\hline & $\begin{array}{l}\text { Monitor activity } \\
\text { during project } \\
\text { completion }\end{array}$ & $\begin{array}{l}\text { Lecturers guide students } \\
\text { to write the results of } \\
\text { group work }\end{array}$ & $\begin{array}{l}\text { Students together orderly } \\
\text { write down the results of } \\
\text { the discussion as material } \\
\text { in completing the project }\end{array}$ & Enough Good & Good \\
\hline \multicolumn{6}{|c|}{ 5. Evaluate Test Results } \\
\hline & $\begin{array}{l}\text { Evaluate project } \\
\text { progress }\end{array}$ & $\begin{array}{l}\text { Lecturers evaluate the } \\
\text { progress of projects } \\
\text { made by students }\end{array}$ & $\begin{array}{l}\text { Some students still look } \\
\text { confused in the project to } \\
\text { be made }\end{array}$ & Enough Good & Good \\
\hline & $\begin{array}{l}\text { Feedback in } \\
\text { learning }\end{array}$ & $\begin{array}{l}\text { Lecturers provide } \\
\text { feedback as } \\
\text { reinforcement of subject } \\
\text { matter }\end{array}$ & $\begin{array}{l}\text { Some students were not } \\
\text { enthusiastic when the } \\
\text { lecturer gave feedback as } \\
\text { a reinforcement of the } \\
\text { subject matter. }\end{array}$ & Enough Enough & Good \\
\hline \multirow[t]{2}{*}{6} & Evaluating Experience & & & & \\
\hline & $\begin{array}{l}\text { Reflections on } \\
\text { project activities } \\
\text { and results }\end{array}$ & $\begin{array}{l}\text { The lecturer and } \\
\text { students reflect on the } \\
\text { activities and results of } \\
\text { the projects that have } \\
\text { been made }\end{array}$ & $\begin{array}{l}\text { Students look enthusiastic } \\
\text { about reflecting on the } \\
\text { activities and results of } \\
\text { projects that have been } \\
\text { made. }\end{array}$ & Good & Excellent \\
\hline
\end{tabular}


Jurnal Prima Edukasia, 8 (1), 2020 - 71

Endang Widi Winarni, Endina Putri Purwandari

Based on lecturer and student activities in the third cycle, there are 7 learning activities already in the Good category, namely asking questions to determine fundamental questions, determining relevant topics and conducting in-depth investigations, working on MFIs, creating timelines and deadlines for completing projects, activities monitoring for completing projects, evaluating project progress, and feedback in learning. There are three aspects in the excellent category, namely creating a group design, explaining the project completion, and reflection on project activities and results. The observations of learning implementation showed that the class action research was successful and the cycle stopped.

\section{Description of Scientific Attitude Aspects}

The results of scientific attitude assessment are a science attitude observation sheet. The scientific attitude in this study includes an attitude for environmental care and health care. The environmental care descriptors, include maintaining environmental cleanliness, showing environmental care to reduce waste, caring for the plants, and caring for the abiotic conditions. The health care descriptors include maintaining health, caring for the health condition, health care for plants around, and showing health care attitudes towards the surrounding abiotic conditions. The analysis of scientific attitude assessment in cycles I, II, and III presented in Table 2.

Table 2. Scientific Attitude Assessment in Cycles I, II, and III

\begin{tabular}{|c|c|c|c|c|c|c|}
\hline \multirow{2}{*}{ Cycle } & \multirow{2}{*}{ Scientific Attitude } & \multicolumn{4}{|c|}{ Percentage } & \multirow[t]{2}{*}{ Total } \\
\hline & & Poor & Enough & Good & Excellent & \\
\hline \multirow[t]{2}{*}{ I } & Environmental care & $6,06 \%$ & $39,40 \%$ & $42,42 \%$ & $12,12 \%$ & $100 \%$ \\
\hline & Health care & $3,03 \%$ & $39,40 \%$ & $48,49 \%$ & $9,09 \%$ & $100 \%$ \\
\hline \multirow[t]{2}{*}{ II } & Environmental care & $0 \%$ & $27,27 \%$ & $60,61 \%$ & $12,12 \%$ & $100 \%$ \\
\hline & Health care & $0 \%$ & $39,40 \%$ & $51,52 \%$ & $9,09 \%$ & $100 \%$ \\
\hline \multirow[t]{2}{*}{ III } & Environmental care & $0 \%$ & $0 \%$ & $39,40 \%$ & $60,61 \%$ & $100 \%$ \\
\hline & Health care & $0 \%$ & $0 \%$ & $36,36 \%$ & $63,64 \%$ & $100 \%$ \\
\hline
\end{tabular}

Table 2 shows the scientific attitude in the first cycle in good and excellent categories by $54.54 \%$ and health care attitudes in good and excellent categories by $57.58 \%$. The literacy aspects in the first cycle have not reached $80 \%$. The scientific attitude in the second cycle for the environmental care in the good and excellent category was $72.73 \%$ and the health care in the good and excellent category was $60.61 \%$. It showed that the literacy aspects in the second cycle had not reached a percentage of $80 \%$. The scientific attitude in the third cycle for environmental care in the good and excellent category by $100 \%$ and the attitude of health care in the good and excellent category by $100 \%$. It shows that the literacy aspects in cycle III have reached a percentage of $80 \%$. The results of three cycles of scientific attitudes seen in Figure 1. It shows that the scientific attitude reached the highest percentage for environmental care from $53.54 \%$ in the first cycle to $100 \%$ in the third cycle that increase by $46.36 \%$. The lowest percentage value is the health care attitude from $57.58 \%$ in the first cycle to $100 \%$ in the third cycle which means an increase of $42.42 \%$.

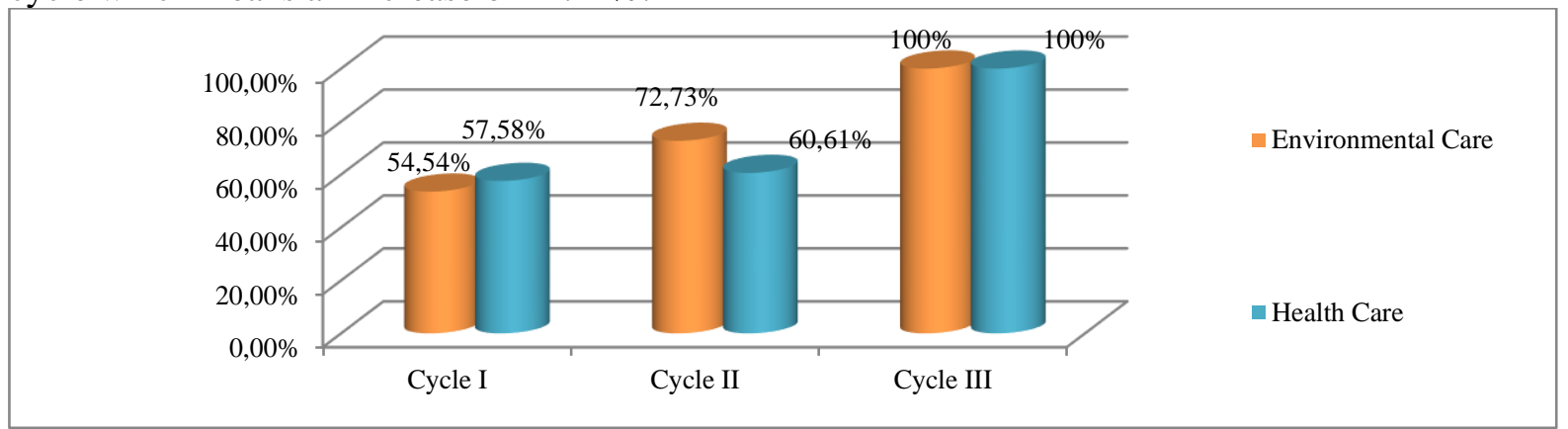

Figure 1. The result of scientific attitude in three cycles

\section{Description of Science Context}

The results of scientific context formed student report assessment sheets with rubrics that include the theory and application in daily life. The results of scientific context analysis in cycles I, II, and III shows in Table 3. It shows that the success criteria for science context about 68.5 in the first cycle, increased to 81.55 in the second cycle, and reached 85.13 in the third cycle. The number of students who 
Jurnal Prima Edukasia, 8 (1), 2020 - 72

Endang Widi Winarni, Endina Putri Purwandari

achieved a minimum score of 75 in the first cycle was 21 people or classical completeness was $52.5 \%$, increased to 40 people with the percentage of literacy aspects reached $100 \%$ in cycle II, and cycle III.

Table 3. The Assessment of Science Context in Cycle I, II, and III

\begin{tabular}{lccc}
\hline \multirow{2}{*}{ Score } & \multicolumn{3}{c}{ Value of Science Context } \\
\cline { 2 - 4 } & Cycle I & Cycle II & Cycle III \\
\hline Highest & 65 & 75 & 80 \\
Lowest & 75 & 88 & 90 \\
Average & 68.50 & 81.55 & 85.13 \\
Students with a minimum grade of 75 & 21 & 40 & 40 \\
Percentage of Completeness & $52.5 \%$ & $100 \%$ & $100 \%$ \\
\hline
\end{tabular}

The results of scientific context in cycles I, II, and III seen in Figure 2. It shows that the scientific context in the first cycle of 75 or categories have not been successful. The second cycle of 88 or has exceeded the success criteria of 75 , and in the third cycle has reached an average of 90.

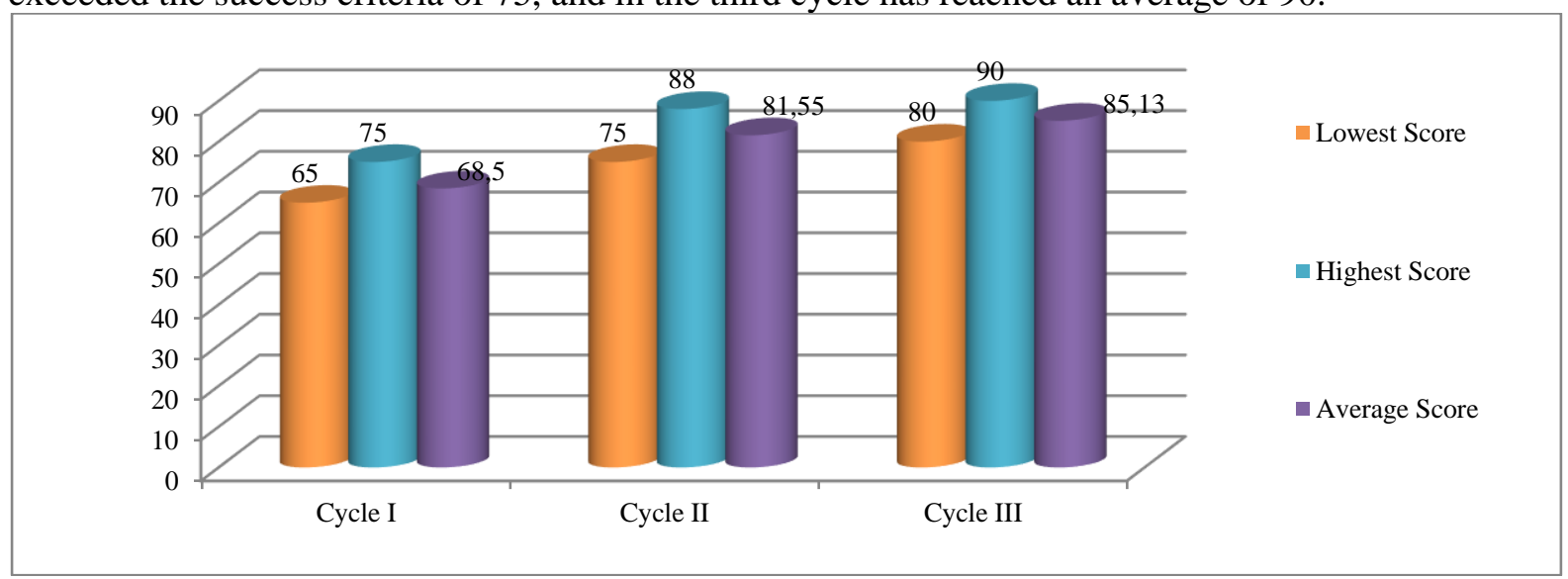

Figure 2. The scientific context results

\section{Description of Science Knowledge Aspects}

The assessment for students' scientific knowledge used the posttest evaluation given after the learning process takes place in each cycle. The questions are given from topics: (1) the plant's growth in three questions; (2) the ecosystems interaction between abiotic and biotic in four questions; (3) the human body metabolism from digestive and circulatory system in four questions. The analysis of scientific knowledge in cycles I, II, and III presented in Table 4. It shows that the success criteria for literacy aspects in scientific knowledge about 45.53 in the first cycle, increased to 76.55 in the second cycle, and reached an average of 84.75 in the third cycle. The number of students who achieved a minimum score of 75 in the literacy aspects of the first cycle of knowledge as many as 7 people or completeness classically by $17.5 \%$, increased to 34 people or the percentage of completeness of the literacy aspects of science knowledge classically reached $85 \%$ in the second cycle, and increased to 40 people or reach $100 \%$ in cycle III (Figure 3).

Table 4. The Science Knowledge Assessment Cycles I, II, and III

\begin{tabular}{lccc}
\hline \multirow{2}{*}{ Score } & \multicolumn{2}{c}{ Value of Science Knowledge } \\
\cline { 2 - 4 } & Cycle I & Cycle II & Cycle III \\
\hline Highest & 20 & 55 & 70 \\
Lowest & 90 & 98 & 100 \\
Average & 45.53 & 76.55 & 84.75 \\
Students with a minimum grade of 75 & 7 & 34 & 40 \\
Percentage of Completeness & $17.5 \%$ & $85 \%$ & $100 \%$ \\
\hline
\end{tabular}

Figure 3 shows assessment the scientific knowledge on average 45.53 in the first cycle or categories have not been successful, 76.55 in the second cycle or have succeeded the success criteria of 75 , and has reached an average of 84.75 in the third cycle or exceeded the success criteria of 75 . 
Jurnal Prima Edukasia, 8 (1), 2020 - 73

Endang Widi Winarni, Endina Putri Purwandari

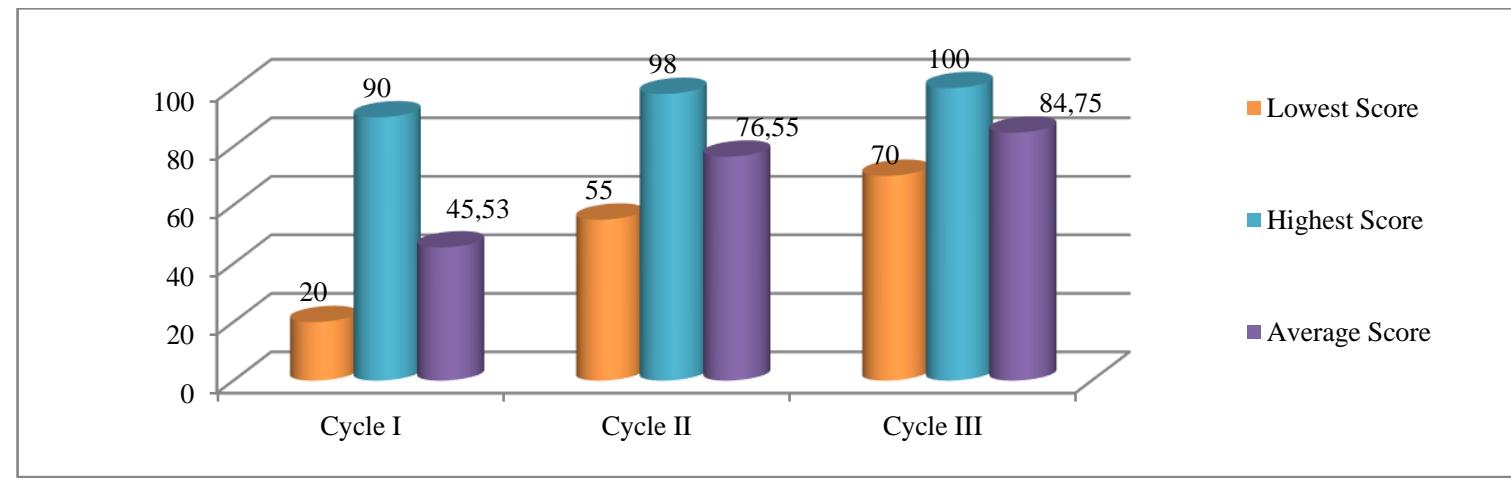

Figure 3. The Assessment of Science Knowledge

Description of Science Competency Aspects

The science competency uses the project assessment sheet with PowerPoint media for cycles I, II, and III presented in Table 5.

Table 5. Science Competency Assessment in Cycle I, II, and III

\begin{tabular}{lccc}
\hline \multirow{2}{*}{ Score } & \multicolumn{3}{c}{ Value of Science Competency } \\
\cline { 2 - 4 } & Cycle I & Cycle II & Cycle III \\
\hline Highest & 60 & 72 & 80 \\
Lowest & 70 & 86 & 90 \\
Average & 66,88 & 79,7 & 83,6 \\
Students with a minimum grade of 75 & 16 & 34 & 40 \\
Percentage of Completeness & $40 \%$ & $85 \%$ & $100 \%$ \\
\hline
\end{tabular}

Table 5 shows the average of success criteria for literacy aspects in science competency about 66.88 in the first cycle, increased to $79.7 \%$ in the second cycle, and reached an average of 83.6 in the third cycle. The number of students who achieved a minimum score of 75 in the literacy aspects of the first cycle competencies as many as 16 people or completeness classically by $40 \%$, increased to 34 people or the percentage of literacy aspects of classical knowledge of science reached $85 \%$ in the second cycle, and increased to 40 people or reach $100 \%$ in cycle III (see Figure 4). Based on Figure 4, it shows assessment for science competency on average 66.88 in the first cycle or the category has not been successful, in the second cycle of 86 or have succeeded of 75 , and in the third cycle has reached an average of 90 or have exceeded the success criteria of 75 .

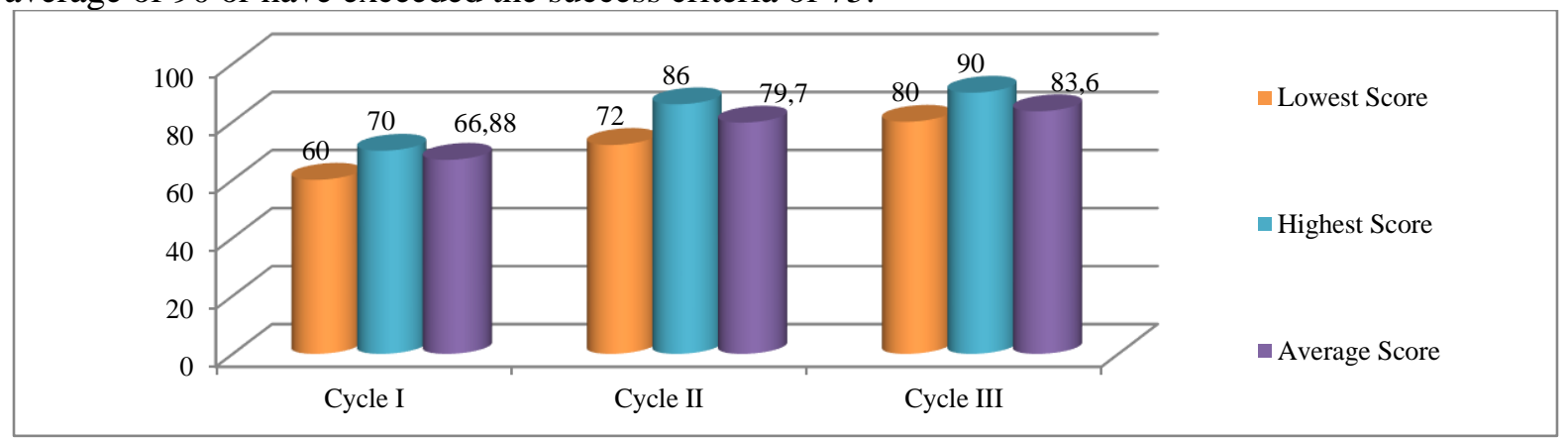

Figure 4. The Assessment of Science Competency

Implementation for the Project-Based Learning model in cycle III shows that there were 7 steps in the Good category and 3 steps in the Excellent category. Project-Based Learning model provides a great opportunity for students to produce interesting and meaningful learning experiences especially for adult students who are ready to enter the workforce (Miller \& Krajcik, 2019).

Discussion

\section{Learning Activity}

Project-Based Learning focuses on questions or problems, which encourage students to collaborate with the concepts and core principles from the discipline. The project definition for students made 
Jurnal Prima Edukasia, 8 (1), 2020 - 74

Endang Widi Winarni, Endina Putri Purwandari

to build a relationship between the activity and conceptual knowledge which is expected to develop into broad and deep learning. Fundamental questions in projects must be commensurate with the activities, products, and performance that occupy their time orchestrated in intellectual tasks. The results showed that there were 7 learning activities in the Good category, namely asking questions to determine the fundamental questions, determining relevant topics and conducting in-depth investigations, working on MFIs, making timelines and deadlines for completing projects, monitoring of activities during project completion, evaluating project progress, and learning feedback. There are three aspects in the Excellent category, namely creating a group design, explanation of the project completion, and reflection on project activities and results.

Projects involve students conducting investigations from the design process, decision-making, problem discovery, problem-solving, discussion, or model development process. Project-based learning involves real-life challenges, focusing on authentic questions, and the solutions in real life. The research findings are in line with Project-based learning is an innovative learning model or approach, which emphasizes contextual learning through complex activities (Aránguiz et al., 2020). the PjBL learning model has seven characteristics as follows involving students directly in learning, connecting learning with the real world, implementing on a research-based, involving various research sources, combining with knowledge and skills, carried out from time to time, and ended with a certain product (Abidin, 2014; Abidin et al., 2017).

\section{Scientific Attitude}

The scientific attitude of environmental care in the first cycle in both good and excellent categories by $54.54 \%$ increased to $72.73 \%$ and increased to $100 \%$ in the third cycle. The health care attitudes in both good and excellent categories by $57.58 \%$ increased to $60.61 \%$ in the second cycle and increased to $100 \%$ in the third cycle. It means that it reached the success criteria and terminated the cycle. The attitude has three components, namely cognitive is a belief in objects, affective is a feeling towards the object attitude, and cognitive is a tendency to act in a real way to respect the object (Winarni, 2012). The attitude based on knowing, willing, conscious, to characterize. Attitude is one of the personality elements possessed by someone to determine actions and behave towards an object accompanied by feelings, acceptance, or rejection (Zhao et al., 2020).

The choice of learning models and approaches according to the content and context characteristics that can have an impact on learning outcomes for scientific attitudes. The use of project-based learning has a different effect on students' scientific attitudes without having to be specifically addressed (Handayani et al., 2015). Each time a student meeting trains the scientific attitude so that if carried out continuously, the science values will be internalized and can influence students' attitudes (Winarni, 2016). The findings of this study are in line with the OECD which explains that the scientific framework in PISA includes how they respond to science, appreciate and assess scientific approaches, awareness, and concern for environmental problems (Organisation for Economic Co-operation and Development, 2016).

\section{Science Context}

Scientific literacy aspects measured by the ability of students to connect the material with events in daily life, namely material growth and development of plants associated with examples of disturbances found in the surrounding environment, the material interaction of abiotic and biotic components in the ecosystem that associated with balanced, semi-balanced, and unbalanced ecosystems in the surrounding environment, and the digestive system and circulatory system that associated with interference and healing system.

The PjBL application in science lectures shows that the scientific context average about 68.5 in the first cycle, increased to 81.55 in the second cycle, and reached 85.13 in the third cycle. The number of students who achieved a minimum score of 75 in the first cycle was 21 people or classical completeness was $52.5 \%$, increased to 40 people or the percentage of scientific literacy aspects reached $100 \%$ in cycle II and cycle III. The results of this study are in line with Susanti, that project-based learning is an innovative learning model or approach, which emphasizes contextual learning through complex activities to enhance student knowledge contextually (Susanti et al., 2019).

It can happen because project-based learning has characteristics, such as students make decisions and frameworks, solutions are not predetermined, students design processes to achieve results, students 
responsible for obtaining and managing the information collected, evaluation continuously, students regularly look back at what they do, evaluation the final product quality, and the class has tolerance and change the atmosphere. It is better to involve students in learning science, namely knowledge, attitudes, context, skills, and various competencies. Students will be directly involved in learning that not only provide factual knowledge to memorize, but also use their thoughts, attitudes, and process to find knowledge as a problem-solving in their environment. The Organisation for Economic Co-operation and Development (2016) explains the scientific framework in PISA 2015 context areas are issues at the personal, local, national, and global levels involving science and technology. The scientific context used consists of health, natural resources, the environment within the boundaries of science and technology (Organisation for Economic Co-operation and Development, 2016).

\section{Science Knowledge}

Theoretically, science is a branch of all-natural phenomena in the form of facts, concepts, and principles that are proven through scientific processes. According to Winarni that science is a collection of knowledge obtained using observations of natural phenomena that are systematically arranged and used to solve problems in life (Winarni, 2018a). Likewise, Sulaeman states that one of the learning models that supports the 2013 curriculum is PjBL (Sulaeman, 2016). This model is process-centered, timed, focused on problems, and involves students to solve problems through scientific methods (Miller \& Krajcik, 2019).

The results for science knowledge aspects show that on average in the first cycle of 45.53 increased to 76.55 in the second cycle and reached an average of 84.75 in the third cycle. The number of students who achieved a minimum score of 75 in the first cycle was 7 people or classical completeness was $17.5 \%$, increased to 34 people or the percentage of mastery literacy aspects of scientific knowledge reached $85 \%$ in the second cycle, and increased to 40 people or reached $100 \%$ in cycle III. In line with the results of research by Arisanti, et al that the PjBL model can improve students' mastery of concepts (Arisanti et al., 2017). Fitri said that the PjBL model requires students to be active in problem-solving so that they can practice their higher-order thinking skills (Fitri et al., 2018). OECD explains the scientific framework in the PISA 2015 area, namely knowledge consisting of content, procedural, and science epistemic (Organisation for Economic Co-operation and Development, 2016). This knowledge includes nature and content knowledge, procedural knowledge, and epistemic knowledge.

\section{Science Competency}

The PjBL model can improve the literacy aspects of competencies. The number of students who reach a minimum score of 75 cycles I about 16 people or completeness classically by $40 \%$, increased to 34 people or the percentage of literacy completeness aspects of science competencies classically reaches $85 \%$ in cycle II and increased to 40 people or $100 \%$ in cycle III.

Handayani research shows the basic science competencies will be fully mastered if students have scientific performance abilities based on scientific attitudes such as making careful observations, measuring, organizing, and analyzing data (Handayani et al., 2015). Organizing their thoughts and knowing when and how to apply their knowledge to solve the problem. Relevant research results on scientific literacy that include attitudes, processes, competencies/skills, and knowledge. Elementary students' understanding of disaster response increases after participating in mobile learning using an Android-based Learning Application as one form of technology literacy for students (Winarni et al., 2018). Literacy for competencies aspects is the ability to interpret data including basic abilities in finding patterns, making tables, making graphics, or other forms of interpretation work (Roohr et al., 2014). These competence aspects focused on the student's ability to produce work presenting observations or experiments in the form of animated powerpoints about the basic concepts of science. The ability to interpret data and facts scientifically requires students to master some abilities change data from one type to another type of presentation; analyze, interpret and draw appropriate conclusions; identify assumptions, evidence, and reasoning in science texts; distinguish the argument based on scientific evidence and theory; and evaluate scientific arguments and evidence from different sources.

The OECD explains that scientific literacy is the ability to engage with issues and ideas related to science as reflective citizens (Organisation for Economic Co-operation and Development, 2016). Someone who has scientific literacy is willing to engage in reasoning discourse on science and technology. It requires competence explains scientific phenomena so that they recognize, offers and evaluates explana- 
tions for various natural and technological phenomena; evaluating and designing scientific research to describe and assess scientific investigations, and to propose ways of handling scientific questions; and interpreting data and scientific evidence to analyze and evaluate data, claims, and arguments in various representations and draw appropriate scientific conclusions (Chiu \& Lin, 2019). All competencies also require students' abilities in terms of collaborating, communicating, thinking critically, and evaluative.

The relationship between literacy aspects is following Masithoh that someone who has scientific literacy is willing to engage in reasoning discourse about science and technology (Masithoh, 2018). Based on PISA framework, scientific literacy requires competence to explain scientific phenomena such as (1) acknowledge, offer, and evaluate explanations for various natural and technological phenomena; (2) evaluating and designing scientific research such as describing and assessing scientific inquiry, and proposing ways to handle scientific questions; and (3) interpret scientific data and evidence, include analyze and evaluate data, claims, and arguments in various representations and draw appropriate scientific conclusions (Organization for Economic Co-operation and Development, 2019).

\section{Conclusion}

Project-Based Learning (PjBL) in Natural Sciences subjects can improve the learning activities indicated by 7 activities in the Good category, namely: (1) determine fundamental questions, (2) determine the relevant topics and conducting in-depth investigations, (3) working on MFIs, (4) making timelines and deadlines for completing projects, (5) monitoring activities during project completion, (6) evaluating project progress, and (7) feedback in learning. There are three aspects in excellent category, namely: (1) creating a group design, (2) making an explanation of the selection of a way in project completion, and (3) reflection on project activities and results.

The application of the Project-Based Learning model can improve literacy aspects of environmental care attitudes in the first cycle in both good and very good categories by $54.54 \%$ increased to $72.73 \%$ and became $100 \%$ in the third cycle. For health care, attitudes in both good and very good categories by $57.58 \%$ increased to $60.61 \%$ in cycle II, and $100 \%$ in cycle III means that it has reached the criteria for success and the cycle terminated. The number of students who achieved a minimum score of 75 in cycle I was 21 people or classical completeness was $52.5 \%$, increased to 40 people or literacy completeness aspects of the scientific context reached $100 \%$ in cycle II and cycle III. The number of students who achieved a minimum score of 75 in the first cycle was 7 people or classical completeness was $17.5 \%$, increased to 34 people or the literacy aspect of scientific knowledge was $85 \%$ in the second cycle, and increased to 40 people or reached $100 \%$ in cycle III. The number of students who achieved a minimum score of 75 cycles I was 16 people or $40 \%$ completeness classically, increased to 34 people or literacy completeness aspects of classical competence reached $85 \%$ in cycle II and increased to 40 people or $100 \%$ in cycle III.

\section{References}

Abidin, Y. (2014). Desain sistem pembelajaran dalam konteks kurikulum 2013. Refika Aditama.

Abidin, Y., Mulyati, T., \& Yunansah, H. (2017). Pembelajaran literasi strategi meningkatkan kemampuan literasi matematika, sains, membaca, dan menulis. Bumi Aksara.

Aránguiz, P., Palau-Salvador, G., Belda, A., \& Peris, J. (2020). Critical thinking using project-based learning: The case of the agroecological market at the "Universitat Politècnica de València." Sustainability, 12(9), 3553. https://doi.org/10.3390/su12093553

Arisanti, W. O. L., Sopandi, W., \& Widodo, A. (2017). Analisis penguasaan konsep dan keterampilan berpikir kreatif siswa sd melalui project based learning. EduHumaniora | Jurnal Pendidikan Dasar Kampus Cibiru, 8(1), 82. https://doi.org/10.17509/eh.v8i1.5125

Chiu, M.-H., \& Lin, J.-W. (2019). Modeling competence in science education. Disciplinary and Interdisciplinary Science Education Research, 1(1), 12. https://doi.org/10.1186/s43031-0190012-y

Cook, K., Buck, G., \& Park Rogers, M. (2012). Preparing biology teachers to teach evolution in a project-based approach. Science Educator, 21(2), 18-30. https://eric.ed.gov/?id=EJ997503

Fitri, H., Dasna, I. W., \& Suharjo, S. (2018). Pengaruh model project based learning (PjBL) terhadap kemampuan berpikir tingkat tinggi ditinjau dari motivasi berprestasi siswa kelas IV sekolah dasar. 
Jurnal Prima Edukasia, 8 (1), 2020 - 77

Endang Widi Winarni, Endina Putri Purwandari

Briliant: Jurnal Riset Dan Konseptual, 3(2), 201. https://doi.org/10.28926/briliant.v3i2.187

Fitzgerald, A., \& Smith, K. (2016). Science that matters: Exploring science learning and teaching in primary schools. Australian Journal of Teacher Education, 41(4), 64-78. https://doi.org/10.14221/ajte.2016v41n4.4

Handayani, I. D. A. T., Karyasa, I. W., \& Suardana, I. N. (2015). Komparasi peningkatan pemahaman konsep dan sikap ilmiah siswa SMA yang dibelajarkan dengan Model Pembelajaran Problem Based Learning dan Project Based Learning. Jurnal Pendidikan Dan Pembelajaran IPA Indonesia, 5(1).

Kusumaningrum, S., \& Djukri, D. (2016). Pengembangan perangkat pembelajaran model project based learning $(\mathrm{PjBL})$ untuk meningkatkan keterampilan proses sains dan kreativitas. Jurnal Inovasi Pendidikan IPA, 2(2), 241. https://doi.org/10.21831/jipi.v2i2.5557

Masithoh, D. (2018). Teachers' scientific approach implementation in inculcating the students' scientific attitudes. Jurnal Prima Edukasia, 6(1), 32. https://doi.org/10.21831/jpe.v6i1.14282

Miller, E. C., \& Krajcik, J. S. (2019). Promoting deep learning through project-based learning: a design problem. Disciplinary and Interdisciplinary Science Education Research, 1(1), 7. https://doi.org/10.1186/s43031-019-0009-6

Organisation for Economic Co-operation and Development. (2016). PISA 2015 assessment and analytical framework: Science, reading, mathematic, financial literacy and collaborative problem solving. OECD Publishing. https://doi.org/10.1596/28293

Organization for Economic Co-operation and Development. (2019). PISA 2018 assessment and analytical framework. OECD. https://doi.org/10.1787/b25efab8-en

Roohr, K. C., Graf, E. A., \& Liu, O. L. (2014). Assessing quantitative literacy in higher education: An overview of existing research and assessments with recommendations for next-generation assessment. ETS Research Report Series, 2014(2), 1-26. https://doi.org/10.1002/ets2.12024

Sari, I. K. (2018). The effect of problem-based learning and project-based learning on the achievement motivation. Jurnal Prima Edukasia, 6(2), 129-135. https://doi.org/10.21831/jpe.v6i2.17956

Sulaeman, M. (2016). Aplikasi project based learning (PBL) untuk membangun keterampilan berpikir kritis dan kreatif siswa. Bioma.

Susanti, S., Susilowibowo, J., \& Hardini, H. T. (2019). Effectiveness of project-based learning models to improve learning outcomes and learning activities of students in innovative learning. $K n E$ Social Sciences, 3(11), 82. https://doi.org/10.18502/kss.v3i11.4000

Winarni, E. W. (2012). Inovasi dalam pembelajaran IPA. FKIP UNIB.

Winarni, E. W. (2016). The effect of discovery learning model of environmental care attitude and compost understanding concept for fifth grade students at SDN 11 in Bengkulu City. International Conference of Elementary School Teacher Education (ICESTE).

Winarni, E. W. (2018a). Pendekatan ilmiah dalam pembelajaran kreatif dan inovatif. FKIP Unib Press.

Winarni, E. W. (2018b). Teori dan praktik penelitian kuantitatif kualitatif penelitian tindakan kelas $(P T K)$ reseach and development $(R \& D)$. Bumi Aksara.

Winarni, E. W., \& Purwandari, E. P. (2019). Sumber belajar literasi lingkungan berbasis ICT. UNIB Press.

Winarni, E. W., Purwandari, E. P., \& Hervianti, Y. (2018). Mobile educational game for earthquake disaster preparedness in elementary school. ARPN Journal of Engineering and Applied Sciences, 13(7).

Zhao, X., Wang, J., Wang, M., Li, X., Gao, X., \& Huang, C. (2020). A new model for assessing the impact of environmental psychology, e-learning, learning style and school design on the behavior of elementary students. Kybernetes, ahead-of-p(ahead-of-print). https://doi.org/10.1108/K-092019-0579 